\title{
Impact of Covid-19 on Fisheries Sector
}

\author{
S. Rajamohan \\ Senior Professor \& Director, Alagappa Institute of Management \\ Alagappa University, Karaikudi, Tamil Nadu, India

\section{S. Kanchana} \\ Ph.D. Research Scholar, Alagappa Institute of Management \\ Alagappa University, Karaikudi, Tamil Nadu, India \\ https://orcid.org/0000-0002-0470-6591
}

Manuscript ID:

MGT-2021-09013853

Volume: 9

\section{Abstract}

Fisheries sector plays an important role in global food security. Fisheries industry is one of the fastest growing food sectors across the frontiers of nation. The coronavirus pandemic, which has been started in late 2019, is one of the devastating crises that has affected sectors of seafood especially fisheries industry. Fisheries industry is the most highly traded commodities all over the world. This paper highlights the impacts of covid-19 in Fisheries industry market,this study forms a basis from which to focus on the market conditions of the fisheries sector. The purpose of this information paper is to update information on the impact of the COVID-19 pandemic on the fisheries, especially in Tamilnadu region, there were many adjustments by the ministry and the private sector to the deriving situation of the coronavirus pandemic. There has been new challenges, as well as innovations by governments in order to ensure a smooth flow of production as well as consumption pattern of the consumers. The paper relies on information collected through secondary sources (e.g., media articles, newsletters of Tamilnadu fisheries department), and publicly available data.

E-ISSN: 2581-9402

Received: 21.03 .2021

Accepted: 18.05.2021

Published: 01.07.2021

Keywords: COVID-19, Pandemic, Fisheries, Impacts, Market, SDG, Government policy

\section{Introduction}

Fish is one of the greater frequent seafood that we like to give way and along with being delicious, it is also weighted with health benefits. Fish is known to be a depressed-fat huge-quality protein. It contains crucial omega-3 fatty acids and vitamins.

Belton (2014) Fish is also a rich source of calcium, phosphorous and

Rajamohan, S., and

S. Kanchana. "Impact of

Covid-19 on Fisheries

Sector." Shanlax

International Journal of

Management, vol. 9, no. 1, 2021, pp. 25-33.

DOI:

https://oi.org/10.34293/

management.v9i1.3853

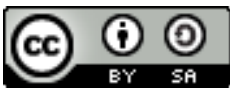

This work is licensed under a Creative Commons Attribution-ShareAlike 4.0 International License. minerals such as iron, zinc, iodine, magnesium, and potassium. The fisheries sector is a significant origin of employment and nutrition, especially in lowincome countries. Additionally, fishery is a deeply traded commodity with shocks to production, distribution, labour, and supply felt all over the world.

Impacts of COVID-19 on the fisheries sector were found to have a great extensive ranging and occurred at many diverse dots in the supply chain of the market. Lockdowns interrupted fisheries trade, followed by brunt on production, labour and livelihoods, and distribution. These impacts constantly occurred concurrently, while others showed overflowing, networked, or fall behind the impacts.

According to FAO (2021), Fish supply, consumption, prices and trade revenues all were declined during the period due to the impact of COVID-19 containment measures.

While there is powerful fluctuation between market segments, and also the overall demand has weakened, resentfully affecting businesses which must also contend with costly logistics, labour challenges and widespread uncertainty. 
Meantime, capture fisheries production is most likely to drop broadly due to reduced fishing effort in many regions as a result of COVID-19 related restrictions on fishing vessel crews and because of market effects associated with the pandemic. On the other hand, again there is powerful valuation according to species, with lower cost, retail-focuses species that may be frozen or otherwise conserved generally faring better in the current environment.

White et al., (2020), Majority of fishers continued fishing during the early months of the pandemic, while a significant number had stopped fishing.

Throughout the early months of the COVID-19 crisis, series experienced severe impacts from the pandemic and its associated restrictions, with many fishing fleets experiencing a substantial decline in activity for the early part of 2020 .

This covid-19 pandemic induced symbolic disruptions to food supply chains around the world.

The key activities in a fisheries supply chain are fishing, production, processing, transport of inputs, distribution, wholesale and retail marketing.

FAO (2021), Each of these activities are of equal importance to the success of the supply chain. If one of the buyers-seller links is ruptured by the disease or containment measures, the outcome will be a cascading chain of disruptions that affects livelihoods and food security. Households experiencing financial distress slow down their spending especially the livelihood of fisherman.

Each stage of the chain liable to the living, screw up or blocked by brunt's arising from COVID-19 and associated measures.

The deflation of household demand, also determined by containment measures (e.g., closure of food services, tourism sites, etc.) affects production, processing and distribution, and causes interruption in international and domestic supply chains of the fisheries sector.

The experience that lives is, fresh or chilled fish which represent most percent of fish consumed - are highly perishable presents further logistical threat in the supply chain. Moreover, the cutback in domestic demand and across the board containment measures influence both a nation's imports and cut down the foreign income, with powerful consequences on a sector highly dependent on international trade.
FAO (2021), In extension, many insurers do not cover business interruptions right to events such as the COVID-19 disease.

The COVID-19 pandemic and consequent restaurant closures had a momentous impact on the fisheries industry. While the exact magnitude of the impact is difficult to calculate, along with several other food products, export revenues of even fisheries has been reaching the declining stage as countries close borders and halt trade.

Fish is presently noticing a composition of challenges feeding from closure of operations, dynamic consumer demands, market approach and logistical problems, and transportation and border restrictions. Supply chain breach generate by interruptions in transportation, trading and labour have hamper both fish farming and commercial fishing operations

For example, restaurants were allowed to open, but the supply chain disruptions became less frequent, and concerns about maintaining social distancing aboard fishing vessels has to relax. Smith (2020), Conversely, the medium- to long-term impacts of the pandemic on the industry were still very much uncertain at the time of this research. As summer when appeared in the Northeast United States, the high season for tourism in many coastal nations was foreseen to be naturally curtailed by the impacts of the pandemic. This could existentially compound objections and issues for the fishing industry, as a number of fisheries away densely on tourists and restaurant sales during this busy season, particularly with a diminished export market.

\section{Review of Literature}

Hon'ble chief Minister of Tamil Nadu speech on 9th feb 2020 that Tamil Nadu has ranked 5th in India in fish production by producing 6.82 lakh ton fish as a result of slew of measures taken such as providing quality fish seeds to the fish farmers, introduction of new fish species, introduction of new technologies and establishing the fish markets for hygiene handling of fish. The back land fisheries sector abutment 14 the living of 2.36 Lakh in land fishers of the State.

Tamilnadu ranks 3rd in total marine fish production of the country during 2017-18. The total 
fish production of Tamil Nadu was predicted at 6.90 Lakh tons during 2018-19. The State find outlet 1.29 Lakh tons of marine commodities and acquire a foreign exchange of Rs.5,591.49 Crore during 2018-19. The policy of Government is to amplify the overall fish production of the State from all the applicable water resources. Hence, Government spot light on adoption of leading technologies and best management practices to boost up the fish production in the State sustainably in tandem with Sustainable Development Goals (SDG).

According to Fisheries policy note (2020-2021), Tamilnadu is blessed with $1,076 \mathrm{~km}$ long coast line and 41,412 sq. $\mathrm{km}$ of continental ledge range with an Exclusive Economic Zone (EEZ) of 1.9 Lakh sq. $\mathrm{km}$, committing to $5.21 \mathrm{Lakh}$ tons of marine fish production. This holds the income of 10.48 Lakh marine fishers. There are 5,806 mechanized and 41,652 classical fishing crafts which are actively matched in fishing.

According to the Tamil Nadu fisheries department mentioned during the year of 2020 that, Tamil Nadu possess 3.83 Lakh effective inland water resources comprising reservoirs, major irrigation tanks, minor inundation tanks, short seasonal tanks, ponds, rivers, backwaters and other water bodies frame. A predicted brackish water area of 56,000 ha is concealed by acquisition fisheries and an area of 6,236 ha is under coastal aquaculture production, mainly shrimp aquaculture. Marine Fisheries of Tamil Nadu has the second longest coastline in the country with a coastal length of $1,076 \mathrm{~km}$ spreading across 13 coastal districts.

According to both the World Health Organization (WHO) and the World Organisation for Animal Health (OIE), the COVID-19 pandemic is being sustained through human-to-human transmission and not through international trade in animals and animal products.

According to Food safety and Nutrition (2021), there is currently no evidence that people can catch COVID-19 from food Consumer demand for packaged and frozen products increased from the second quarter of 2020 as family unit consider to carry up on non-perishable food. FAO (2021), High-value fresh fish and aquatic food demand has decayed as restaurants and hotels have closed, or moderately closed, owing to COVID-19 and associated restriction measures.

Classical Fisheries Management Theory: Classical fisheries management is commencing on a lone stock chart which necessarily contend that the yield of a stock is a function of its size and its generating potential. Afterwards, it is contending that the key aim of fisheries management is to deed this stock at a level where its regenerating ability is equal to its natural mortality, through mesh regulations/ selective fishing. Hence, the classical approach to fisheries management constrains the require to assess the growth and mortality parameters from abused populations, which are then used as input parameters to estimate MSY (i.e., maximum sustainable yield), which is the key objective of fisheries management. FAO (2014) Over time, regulations were gradually introduced to manage fisheries resources to achieve optimum utilization (i.e., maximum sustainable yield) of the fish resources.

According to Pauly, some of these include reducing fishing effort, mesh regulations, closed fishing seasons, and fishing gear restrictions.

Welcomme (2014) defines these as technical measures (e.g., mesh and gear limitations, closed seasons, etc), input controls (e.g., licensing to force achievement and connection, ownership, etc), and output controls (e.g., quotas).

The classical regulations have afterwards been highly carryout in floodplain fisheries. Several management approaches, based on the classical paradigm, have been advanced to manage fisheries essential globally. As a result of one of the bounds of classical fisheries management is Hardin's adversity of the Common's scenario, the basic way to mitigate against this has been to privatize fisheries resources. Later, Pauly proposes individual transferable quotas (ITQ) as substitute way to privatize commons, evidently to impart conservation ethic in exploitation regimes. Other classical management way to secure fish resources builds the portrait of fish refuges, known as marine guarded areas which are essentially meant to act as game reserves or national parks.

The impact of the COVID-19 pandemic on the fisheries market has been significant, the seafood market consists of sales of seafood by entities (organizations, sole traders and partnerships) that 
produce canned seafood, smoke, salt and bone-dry seafood, deaden fresh fish, abandon and pack fresh shellfish, process marine fats and oils and /or freeze seafood. Formulations known as floating factory ships that assemble and process seafood into canned seafood products are also admitted in this industry. The companies in the industry bag and apportion their products over discrete distribution channels to both individual customers and commercial establishments. The fisheries market is segmented into crustaceans; fish and other seafood.

The Food and Agriculture Organization of the United Nations (FAO) report forecast that globally seafood production have been down to 1.7 percent, or three million metric tons (MT), and the trade value of seafood have decreased by USD 5.8 billion (EUR 5 billion). Of that, capture fisheries are expected to decreased production by 2 percent, or 1.9 million.

Prices are also anticipating to abate in 2020 correlated to previous years. The FAO Fish Price Index indicates a drop of 8.3 percent between January and May as correlated to the same period in 2019. Year 2020 was initially trending positive before the COVID-19 outbreak hit. In the year of 2020 the market conditions were expected to be somewhat more positive for the fisheries industry relative to 2019, but the emergence of the COVID-19 pandemic and combine the impacts have concluded previous forecasts largely irrelevant. The closure of restaurants has drastically impacted fisheries demand, leading to the evaporation of food service demand in many important markets. Effects on retail sales have been more diverse, after all with demand for packaged and frozen products boosted as households look to stock up on non-perishable foods. The supply side, as well, has been clashed all over the supply chain. Labour shortages appear from the pandemic have affected all the things from initial production through to the end of the supply chain. These predicts the Fisheries industry overall will continue to be affected negatively by the pandemic even beyond direct.

Misconception and misinformation published in media of fisheries being a carrier of COVID-19 virus and a potential route of transmission to humans is leading to sudden decline in consumption. Sinking in demand, defeat to exports and greater costs of operations are cracking off profit margins of fisheries and seafood companies. The combined fishing industry constitute open catch, capturing, converting, preserving, storing, transporting, marketing and retailing of fish or fish commodities that has been impacted.

With the easing of the lockdown restrictions, the market has however regained lost growth momentum. The pandemic has caused widespread upheaval in fisheries as production has been disrupted, supply chains have been interrupted and consumer spending restricted by various lockdowns, FAO Deputy Director-General Maria Helena Seemed said. "Containment measures have incensed far-reaching changes, many of which are expected to extend in the long term."

According to the scientists of Rutgers university (2020), who published their findings recently in the scientific journal Fish and Fisheries; The fishing industry has been slammed by the pandemic due to the loss of restaurant sales, interruptions in export markets and a recession in seafood prices. Before the pandemic, 70 percent of seafood especially fish spending took place in restaurants, the study notes.

According to the news wise industry (2020), restaurant sales were severely reduced or in some cases lost altogether during stay-at-home orders, when restaurants were closed or limited to takeout. Sales were gradual to rebound as stay-at-home orders were climb and restaurants endure closed or were limited to outdoor dining or serving at reduced capacity.

\section{Objectives of the Study}

- To help the user to understand the market in terms of its potential, influential trends, the challenges and the impacts that the Processed fisheries market is facing due to covid-19.

- To examine about the government policy of Tamilnadu fisheries department in order to face the challenges due to covid-19 pandemic.

- This paper aims at to Identifying factors impacting the fisheries industry especially in Tamilnadu region

\section{Research Methodology}

This descriptive study adopts conceptual 
approach to find out the impacts of COVID-19 under fisheries sector especially in Tamil Nadu region.

\section{Source of Data Collection}

In this study the data has been collected from various secondary sources., from journals articles newsletters working papers etc.

\section{Impacts of Covid-19 on Fisheries Market in Tamil Nadu Region \\ Positive Impacts \\ Fisheries Policy Perspective}

Vision: "Ensuring safety, security and wellbeing of the fishers of Tamil Nadu by providing avenues for safe fishing, sustainable exploitation, optimal utilization and management of fishery resources".

Mission: To develop, manage, conserve and sustainable utilization of all aquatic resources for improving livelihoods, generating employment, food and nutritional security, economic prosperity and ensuring safety and security of fishers.

The Fisheries policy perspective of the Government of Tamil Nadu is to amplify the fish production, to build up the income of the fishers and fish farmers and to establish safety and preservation of fishermen. Government is further improving farming of fast-growing fish diversities through intensive fish culture techniques like Cage culture and Recirculatory Aquaculture System. The Government has taken stride to broaden niche regions like brackish water aquaculture, mariculture including seaweed culture in the State. To enhance the quality and quantity of fish production in the State, the Government spends in necessary framework facilities such as fishing harbours, fish landing centres, marketing infrastructures and fish processing parks. The Government has freshly constituted an absolute marine application wing for protection of fishery resources and competent implementation of Tamil Nadu Marine Fishing Regulation Act (TNMFR). The Government is also contingent upon financial assistance for building fishing crafts, motorization of traditional crafts and fuel to marine fishing crafts. To boost up the inland fish production of the State, Government is enhancing the infrastructure for seed production and fish bringing up in both Government and Private sector and also expand assistance for inputs such as seed, feed and fishing implements.
The Extensive Fisheries Policies of the Government are as Follows

- Protection of traditional fishing rights and welfare of fishermen of Tamilnadu: Special Allowance of Rs.5000/- to Marine Fishermen Families during Lean Fishing Season To alleviate the sufferings of the marine fishermen families during the lean fishing months, the Government is implementing a scheme for providing Special Allowance of Rs.5,000/- to each of the marine fishermen family in 13 coastal districts. The Government has acquire by approving an amount of Rs. 88.41 crore during 2019-20 towards disbursement of special allowance to marine fishermen families. As on 15.3.2020, Rs.65.07 Crore has been credited directly into the bank accounts of $1,30,133$ marine fishermen families of 11 coastal districts through National Electronic Fund Transfer (NEFT). Hon'ble chief Minister of Tamil Nadu speech on 9thfeb2020

- Developing the contemporary living ideals of fishers by carrying out various welfare schemes.

- Increasing the capacity and production of fish from the Inland, Brackish and Marine resources.

Formulation and upgradation of infrastructure aptitudes such as Government Fish Farms, Fishing Harbours, Fish Landing Centres, cold chain, value addition, leading and backward linkages. Brackish Water Fisheries Development Agency (BFDA) is an organisation to transmitting training in scientific approach having contemporary technical inputs, advice the fishermen to upgraded techniques of capture fisheries. Fish Farmers Development Agency (FFDA) is also providing training to fishermen. Appropriate steps should be taken to administer alternative income sources to fishermen during closed season of fishing so that their economic standard and way of living will be enhanced.

- Establishing transparency through e-Governance.

- Bringing about further additional rural employment opportunities over fish culture.

- Bridging the difference between the demand and supply of fish for domestic consumption.

- Re-appraisal of the fishery resources and their capability in the State of Tamil Nadu.

- Preserving fishery resources, stock enrichment and administration through prosecution of 
relevant Acts, Rules and Regulations.

- Capacity building and competence upgradation for fishers and departmental officials for Human Resource Development, Research \& Development and Technological Interference for Fisheries development.

- Exploiting the opportunity of enhancing export market for high value fish and fishery products.

- Empowerment of fisher women in livelihood actions with an appropriate focus on fisher widows.

The State of Tamil Nadu is enriched with marine, freshwater and brackish water fishery assets, which committing and approaching in the direction towards food security and supports employment of more than 10 Lakh fisher folk of the State. The fisheries sector has achieved enormous impetus in terms of its contribution towards economy, nutritional security, rural employment generation and foreign exchange earnings. Tamil Nadu has come up as a colonizing State in India exhibiting steady enhancing of increase in fish production, sustainable consumption of resources, through application of innovative obligation based developmental and welfare schemes for the comprehensive development of this sector

According to Hindustan Times (2021), Government comes up with 7,522 crore packages for fisheries sector, the first tripartite memorandum of agreement has been signed between the department of fisheries, Nabard and the Tamil Nadu government for marine framework upgradation of farmers under the FIDF. The fund will primarily be recycled by the coastal states to invest in infrastructure aptitude for deep-sea fishing, post-harvesting, cage culture and export promotion of fish and marine products.

\section{Negative Impacts}

- Impact on the perception of the of consumers and their attitude in affiliation to fisheries sector

- Impacts on accessible associations (women, indigents communities and emigrants)

- Food preservation and connection to seafood and fishing resources

- The perception of consumers and their behaviour in relation to seafood

- Holidays are being break off, tourists are no protracted inundation the well-known resorts
- Policy indications and institutional responses to deal with the comprehensive impacts

- Socio-economic brunt's i.e., in - Tourist divisions are severely concerned reversing overall decreases in fish sales

- Cruise ships and airlines, which are amidst the greater ardent customers for clam, caviar and craw fish, have diminished or altogether stopped operations

- Changes in selling techniques, such as online sales and direct acquiring of fishery products, emerged; Sales and canned of canned fish boost up in April, but slowed down in May during the year of 2020 .

\section{Sustainable Development Goals}

Jayakumar, (2021) Tamil Nadu is one among the few states to introduce sustainable fisheries management in the marine and inland sector. The introduction of deep-sea fishing vessels to tap the commercially important high valued fishes has paved way for diversifying the fishing activity and has increased revenue to fishers.

The Sustainable Development Goals (SDGs) are universally agreed commitment of the member countries of the United Nations with aim to provide equitable opportunity to all living on the earth with the agenda of leaving no one behind'. The Government of Tamil Nadu has actively involved in taking necessary steps for achieving Sustainable Development Goals in 2030 in line with GOI.

Goal No.1: By 2030, eradicate extreme poverty for all people everywhere addressed the following schemes: Financial assistance to Marine Fishermen Families during Fishing Ban Period. In order to conserve the marine fishery resources, seasonal fishing ban is imposed Special Allowance to Marine Fishermen Families during lean fishing season.

Goal No.2: To achieve target by 2030, double the agricultural Productivity and income of all smallscale food producers address the scheme namely tax exempted High-Speed Diesel (HSD) to fishermen.

Goal No.3: Goal Strengthen the resilience and adaptive capacity to climate related hazards is addressed through the schemes namely World Bank funded scheme CDRRP - Fisheries Management for Sustainable Livelihood - II (FIMSUL - II) project, 
activities improving the 63 socio-economic standards and safety of fishers such as quantity architecture, skill upgradation trainings, providing alternate living existence for sea weed culture.

Goal No.4: To achieve target by 2020, sustainably manage and protect marine and coastal ecosystems is addressed by ensuring coastal security, a scheme of "Online registration of fishing vessels" has been introduced in Tamil Nadu. The Government of India popularized a Central Sector Scheme for "Issuance of Biometric Identity Cards to marine fishermen".

Goal No.5: To achieve target by 2020, adequately administer harvesting and end overfishing, illegal, unreported and unregulated fished. State specific Indicator - Marine Fish Production, the department is taking effective measures to regulate fishing through enforcement of Tamil Nadu Marine Fishing Regulation Act, ban on pair trawling and ban on destructive gears, the target through.,

- Technological interventions to conserve fisheries resources.

- Deployment of artificial reef

- Sea ranching

- Diversification of fishing methods

- Reduction of fishing pressure by providing alternate livelihood activities to fisherfolk

- Management of fisheries resources through participatory approach

Goal No.6: The department has formed Sustainable Development Goals (SDG) Unit vide G.O (Ms) No.184, Animal Husbandry, Dairying and Fisheries (A\&C) Department, dated 26.12.2019. This unit shall work in close co-ordination with SDG cell under Planning and Development department, the Working Groups, State, District and Field officer and other institutions working on SDG. Significant efforts are being taken by the department to achieve the sustainable development goals through implementation of various department schemes.

\section{Challenges Facing by Fisheries Market}

- Lack of judgement on market circumstances: (production, stocks, utilization, trade prices) and heavy-abundant policy interference by countries and state.

- Actual or anticipated supply deficit in the domestic market: There is a tendency against the supply chain undertaking a accelerate for consumption of domestic seafood, as international trade is massively constrained by logistics. Yet, domestic markets also face constraints. It is tough to appraise if this is a long-term movement or not.

- Suppliers that are massively susceptible on food service which are perusing to converting sales to the retail sector, as retailers demand extra commodity. However, suppliers that are used to food service customers have habitually been under much less burden in terms of substantiality essential and find themselves inadequate to meet the sustainability criteria of retailers. There are no signs of retailers adapted to lower their sustainability standards in the current crisis.

- All fisheries massively impacted by a drop in demand also described had a parallel bead in prices for their commodities. Fish and fish products are highly vulnerable on international trade, which has appropriated a blunt hit after country-wide lockdown and termination of food service sectors such as restaurants and hotels. In addition, the lockdown has appeared in logistical issues in the seafood trade, exclusively dead to border restriction and interruption in the supply chain. This concerned the fish protein market more than ever. The busted supply chain and unmade supply of fish protein constitute a shortage of fish protein in aquaculture and cosmetic product production.

- Decreased trade flows due to outrages: The lockdown period, India admits some jolt on the seafood export sector on explanation of logistics issue. The centre had advised the state and other government bodies to afford all logistical bolster for the smooth sectioning of seafood export sector and the situation has improved. On the other hand, globally the sector was affected due to Covid-19 and the associated lockdown. This has appeared in elimination of several orders, diminished and delayed payments, decline of cargo movements, and adversity in appropriating new orders and renewal of existing order. The spread of the COVID-19 novel corona virus has been arousing affect fish trade in Japan, with, for example, prices of natural tuna and other huge-quality fish at Tokyo's Toyosu wholesale 
market affirming amid collapsing demand from restaurants and hotels reversing a decrease in the number of tourists.

The major factors analysing that account for the differential impact in the supply of different fisheries are:

- Amplifications taken by the state authorities to reduce social contact (lockdowns, curfews, etc.).

- Spontaneous measures taken by fishers, collectors, and converting companies to reduce social contact.

- The level of procedure of the actions,with some expulsions, around all surveyed fisheries are uncontrollable and under managed, and the sector is part of the unofficial economy. This blocking the capacity of fishers and workers to access relief aid funding.

\section{Conclusion}

The present study provides us a vast knowledge about the status of fisheries sector especially the state of Tamilnadu i.e., how the covid-19 pandemic has impacted on it. The fishing sector plays a crucial role in development of economy of the country by way of providing proteinaceous food to people, providing employment opportunity to the larger section of the society and contributing to the foreign exchange. The outburst of the corona virus has impacted the fishing industry both in a positive and negative manner and there is a stringent need to adopt appropriate and adequate policy responses to ensure the longterm sustainability of the fishery. Several policy responses (employment extension programs, income replacement initiatives, the Seafood Marketing and Innovation Support Program) have been executed in the province to deal with the pandemic challenges, but more sustainability-oriented approaches are needed in order to secure a vibrant fishery which is a source of food and livelihoods not only for this generation but for future generations too. The State government of Tamilnadu has various schemes for development of fisheries sector. Brackish Water Fisheries Development Agency (BFDA) is an organisation to impart training in scientific way having modern technical inputs, guide the fishermen to improved techniques of capture fisheries. Fish Farmers Development Agency (FFDA) is also providing training to fishermen and also the government has proposed Fisheries policies and infrastructure facilities to protect the entire sector from the pandemic situation and proper steps has been taken to provide alternative income sources to fishermen during closed season of fishing so that their economic standard and way of living will be improved.

\section{References}

Ababouch, L., et al. Causes of Detentions and Rejections in International Fish Trade. FAO, 2005.

Annual Report 2010-11. Central Marine Fisheries Research Institute, Indian Council of Agricultural Research.

Belton, Ben, et al. "Not Just for the Wealthy: Rethinking Farmed Fish Consumption in the Global South." Global Food Security, vol. 16, 2018, pp. 85-92.

Caveen, A.J., et al. "The Risk Assessment for Sourcing Seafood (RASS): Empowering Businesses to Buy Responsibly." Marine Policy, vol. 75, 2017, pp. 1-10.

Demand for Fish and its Transportation and Storage in Selected Cities. National Council of Applied Economic Research, 1980.

Dey, Madan Mohan, et al. "Demand for Fish in Asia: A Cross-Country Analysis." The Australian Journal of Agricultural and Resource Economics, vol. 52, no. 3, 2008, pp. 321-338.

Ellikkal, Adil, and S. Rajamohan. "Effect of Covid-19 Lockdown on Kerala's Job Market." AIJR Preprints, 2020.

Handbook on Fisheries Statistics. Department of Animal Husbandry, Dairying and Fisheries, Ministry of Agriculture, Government of India, 2014.

Jebadurai, D. Joel, and S. Rajamohan. "Value and Quantity Focused Export Performance of Seafood Products in Global Market: Analytical Study." International Journal of Advanced Research in Management and Social Sciences, vol. 6, 2017, pp. 171-177.

Kent, George. "Fish and Nutrition in India." Food Policy, vol. 12, no. 2, 1987, pp. 161-175. 
Kumar, Anjani. "Export Performance of Indian Fisheries: Strengths and Challenges Ahead." Economic and Politically Weekly, vol. 39, no. 38, 2004, pp. 4264-4270.

"National Aquaculture Sector Overview - India." Food and Agriculture Organisation, 2005.

Pomeroy, R.S. and M.J. Williams. Fisheries Comanagement and Small-Scale Fisheries: A Policy Brief. International Centre for Living Aquatic Resources Management, 1994.

Pomeroy, Robert, et al. "Small-Scale Marine Fisheries Policy in Vietnam." Marine Policy, vol. 33, no. 2, 2009, pp. 419-428.

Pomeroy, Robert S., and Michael D Pido. "Initiatives towards Fisheries Co-Management in the Philippines: The case of San Miguel Bay." Marine Policy, vol. 19, 1995, pp. 213-226.

Pomeroy, Robert S. "Small-scale Fisheries Management and Development: Towards a Community-based Approach." Marine Policy, vol. 15, no. 1, 1991, pp. 39-48.
Rajamohan, S., and D. Joel Jebadurai. "Price Movement of Seafood Export in Pre and Post Liberalisation Period of India - A Paired Sample T Test Approach." Pacific Business Review International, vol. 9, 2017, pp. 87-90. Rajamohan, S., et al. "Impact of COVID-19 on Stock Price of NSE in Automobile Sector." International Journal of Advanced Multidisciplinary Research, vol. 7, no. 7, 2020, pp. 24-29.

Smith, Martin D. Fisheries Trade and Sustainable Development. 2014.

The Consumption of Fish and Fish Products in the Asia-Pacific Region based on Household Surveys, FAO, 2014.

The Impact of COVID-19 on Fisheries and Aquaculture Food Systems Possible Responses. FAO, 2021.

White, Easton R., et al. Early Effects of COVID-19 Interventions on US Fisheries and Seafood. 2020.

\section{Author Details}

Dr. S. Rajamohan, Senior Professor \& Director, Alagappa Institute of Management, Alagappa University, Karaikudi, Tamil Nadu, India, Email ID: srajamohan1988@gmail.com

S. Kanchana, Ph.D. Research Scholar, Alagappa Institute of Management, Alagappa University, Karaikudi, Tamil Nadu, India, Email ID: kanchanashivamba@gmail.com 